\title{
THE OLD POOR LAW AND MEDICINE
}

\author{
by
}

\author{
E. G. THOMAS*
}

\section{SUMMARY}

THIS ARTICLE is a survey of the treatment of the sick poor in the counties of Berkshire, Essex, and Oxfordshire from $c .1720$ to 1834 based on parish records. Its general argument is that the sick poor received sympathetic and humane consideration bearing in mind contemporary medical knowledge and the limited facilities available.

General medical aid is first considered - broken limbs, midwifery, eye complaints, etc. This is followed by a section on the use of provincial hospitals and those in London. Parishes readily availed themselves of these institutions and it is suggested that they were not as great a menace as has been often maintained. The role of the dispensaries is also considered. A short section follows on the treatment of the mentally deranged pauper and the use of private asylums. A brief comment is made on the medical contract system. The problem of smallpox in the parishes is examined. It is argued that the effects of the disease were so serious and the use of inoculation so widespread, particularly in the rural areas - that this treatment might well have had some effect on mortality trends in the second half of the eighteenth century. Vaccination also became very popular in the parishes after the first decade of the nineteenth century. This, it is also maintained, made an important contribution to mortality trends - particularly when local authorities were able to treat the whole of the poor.

The action against typhus and cholera is then considered. Examples are cited of progressive authorities who made strenuous attempts to secure a healthier environment and which might, in a small way, have made a contribution towards improving the health of the local communities.

A concluding section attempts to compare the achievements in these three counties with findings in other areas and makes some tentative conclusions. Much more work of this nature clearly needs to be carried out at local level before an overall and definitive picture emerges.

\section{GENERAL MEDICAL CARE}

The Elizabethan legislation referred to the care of the "Lame, Impotent, Old and Blind", 1 though subsequent statutes made little reference to this aspect of poor relief. The Poor Law Commissioners of 1834 merely refer to doctors' contractual salaries. However, medical treatment became an essential part of the overseers' duties and a fair

* E. G. Thomas, Ph.D., 12 Drake Park, Felpham, Bognor Regis, West Sussex PO22 7 QG.

139 Eliz. C.3, 1597-98. 


\section{E. G. Thomas}

measure of success was achieved in this sphere. In the smaller parish there was a reasonable chance of individual attention - more so than in the town where it was likely that treatment would be on a contractual basis from the middle of the eighteenth century.

Ordinary complaints would often be dealt with by a local "nurse" or bonesetter, and serious cases by a professional doctor. Broken limbs proved expensive items always. Thus at Wheatley in Oxfordshire in 1768 a parishioner's broken leg involved bleeding, a messenger's payment for fetching an Oxford doctor, and a four-guinea fee for setting the leg. Setting a girl's thigh at Kidlington in the same county cost three guineas about the average price. Such an indisposition could mean a long absence from work and overseers often paid parishioners' wages during their recovery. At Little Leighs in Essex in 1814 a labourer received twenty-six weeks' additional pay of 10 s. a week when he broke his thigh. ${ }^{2}$

Vestries were sometimes cautious in their payments for this expensive treatment and contracted for part of the sum to be paid, followed by the remainder after a successful cure. At Woodstock, for example, in 1758 it was decided: "to give Mrs. Southam two guineas and a half for the cure of James Smith's leg; one guinea to be paid immediately and the other guinea and a half so soon as we are fully satisfy'd of ye cure." The rest was, in fact, paid three months later. Similarly, at Great Bentley, in north Essex, a local practitioner was given $£ 5$ to attend a poor widow suffering from a leg ailment but there was a proviso to the effect that $£ 5$ more was to be given for a perfect cure, but if the leg were not "cured firm and sound" only the original fee was to be paid. ${ }^{3}$

Further expenses might attend leg complaints. In the Epping Forest area the overseer of Theydon Garnon "gave John Horth a quart of wine on the day his leg was amputated" and the parish incurred further expense in providing a wooden leg, $6 s$., a pair of crutches, $9 d$., and a bell, $6 d$. In the Oxfordshire parish of Dorchester "wooden legs for Aron Tucker's wife" were bought and subsequently repaired at parish expense. 4

Eye complaints occur frequently in parish accounts. At Banbury $£ 213 s .6 d$. was paid for a cure, whilst the vestry at Midgham in Berkshire paid a pension for ten years to a woman "on account of her eyesight being bad which renders her incapable of doing anything for a livelihood." 5 The overseers of Prittlewell in Essex covered the costs of teaching a blind boy to play the violin: "Pd. Jas. Ambrose a quarter year's salary for teaching the blind boy music during Michaelmas, 13s. $1 \frac{1}{2} d$. For a green knap cloth bag for W. Robjent's violin $7 d$. For violin strings, $3 s$. 11d."6

Occasionally a parishioner would be sent to hospital for specialist treatment. The Woodford overseers in Essex paid the expenses for a visit to the Sea Bathing Infirmary when a parishioner suffered from "a disorder in the eye". ${ }^{7}$

Overseers' records consistently refer to other forms of medical relief - trusses, irons,

\footnotetext{
2 Bodleian Library, Oxford (hereinafter BL), MS.D.D.Par. Wheatley C.5; Kidlington parish chest, overseers' accounts; Essex Record Office (hereinafter ERO), D/P 37/12.

3 Woodstock parish chest, vestry minutes; ERO, D/P 171/8/2.

4 ERO, D/P 152/12/1, 1727; Dorchester parish chest, overseers' accounts 1786.

5 Banbury Borough Library, vestry minutes; Berkshire Record Office (hereinafter BRO), D/P 143/12.

6 ERO, D/P 183/12/2, 1788.

7 E. J. Erith, Woodford, Essex, 1600-1836, Chelmsford, Essex County Council, 1950, p. 56.
} 
pills, breast cures, oil, treatment for "the stone", and bleeding. At Abbess Roothing in mid-Essex leeches were bought for poor parishioners. ${ }^{8}$ The Chelmsford overseers hired transport to assist sick poor: "Pd. Wakelyn for bringing Dame Axx in the sedan chair being sick, $1 s .6 d .9$

Midwifery expenses were often paid and considerable sums expended over and above an allowance. At Islip in Oxfordshire, for example, the midwife's fee was paid, firewood and candles bought, and the grocer's bill covered, which included sugar, nutmeg, and oatmeal. Bread and beer were provided "at the time of her crying out" and a christening party paid for. This is an example from a small parish where perhaps twenty people would be in need of relief and when pauper births would be comparatively few. However, it suggests that in the closely-knit communities where the wants of most were known, relief could be generous and effective. The humanity of the local doctor could make itself felt too. At Drayton in Berkshire in 1816 the doctor's bill was $£ 20$ for a half year. However, "through the Philanthropy and Disposition of Mr. Hayward which he is well known to possess he only charged the parish nine pounds". Some doctors treated the poor free. John Morley at Halstead in Essex, for instance, looked after the poor for fifty years without a fee, and in the 1790s Dr. Wood organized a free dispensary at Colchester. 10

Generally speaking the parish authorities were sympathetic and generous in their approach to medical care. The account books often reveal genuine humanitarian understanding of local needs - a fact perhaps not emphasized enough in studies of poor law administration.

\section{HOSPITAL TREATMENT}

From the 1730s parishes began to use the provincial hospitals. There were only two in London and five in the whole of England in 1700, but by the 1780s London had seven and the Provinces thirty. The peak period for Provincial Foundations appears to have been between 1735 and 1775 when twenty-one were established.11 The three counties used hospitals ranging from Bath to Salisbury to Margate. For example, the Vestry at Coleshill in Berkshire decided: "We, whose names are subscribed do agree at a Vestry meeting this day held that Thomas Tibbold ye Elder go down to Bath to enjoy the benefit of ye General Hospital." $£ 3$ was paid as caution money. Abingdon paid $£ 5$ in 1834. There are also some references to "salt water" treatment and from Hungerford in 1789 a boy was sent to Southampton "to be dipped he having been bit by a mad dog." Burford used the Bath Hospital and paid the caution money which was to be refunded if the patient returned. 12

8 ERO, D/P 145/12, 1824.

9 ERO, 94/12/8.

10 BL, MS.D.D.Par. Islip b.10; BRO, D/P 48/12/2; A. F. J. Brown, Essex at work, 1700-1815, Chelmsford, Essex County Council, 1969, p. 142.

11 Brian Abel-Smith, The hospitals, 1800-1948, London, Heinemann Educational, 1964, p. 4. J. Woodward, To do the sick no harm, London, Routledge \& Kegan Paul, 1974, p. 36. See also, John Howard, An account of the principal lazarettos in Europe, Warrington, W. Eyres for T. Cadell, 1789.

12 BRO, D/P 30/8/1; 2/12/4; 71/8/2; Burford parish chest, overseers' accounts; Hungerford also paid contributions to Bath Hospital and Salisbury Infirmary. Leamington Spa was used by the village of Tysoe in Warwickshire: A. W. Ashby, One hundred years of Poor Law administration in a Warwickshire village [Tysoe], Oxford, Clarendon Press, 1932, p. 132. 


\section{E. G. Thomas}

The poor were also given greater opportunities in the second half of the eighteenth century with the founding of dispensaries. Clewer in Berkshire used the Windsor institution, for example, and Colchester organized one in the 1790s, which was open twice a week initially and subsequently available daily. 13 The therapy administered at such dispensaries was possibly no better than that available in the hospitals, or that given by the local parish doctor, but these establishments might well have taught the importance of cleanliness, ventilation, and so on, to a number of people who would have had no other source of help. 14

The Oxfordshire and Berkshire parishes were fortunate in having access to the Radcliffe Infirmary, founded in 1770 . By 1830 at least eighty Oxfordshire parishes thirty per cent - were contributing to a special scheme, paying sums up to six guineas a year. In Berkshire thirty parishes joined - some twenty per cent. The Henley Authorities used interest on the capital of a $£ 175$ legacy of Navy Stock to cover expenses for this scheme. 15

A standard method of entry was devised because of the large number of patients in the eighteenth century. In 1770 the Wheatley overseers paid for a book of orders from the Infirmary and two years later began forwarding an annual fee of two guineas. In 1776 the parish paid three shillings "for horse and cart to draw Thomas Wager to the Infirmary". The turnpike cost two shillings and a man to accompany him received one shilling. The Culham Overseer recorded the payment for "shifts petticoat stockings caps and aprons for Elizabeth Cook's daughter to go to the Infirmary" in 1794 and in 1816 the same parish paid for chaise hire. 16

As a result of the Radcliffe Scheme the Oxfordshire parishes, and those in Berkshire with reasonable access to Oxford, concentrated their financial resources there. Places like Henley, however, were near enough to use the London hospitals. Essex certainly did so and parish accounts refer to Chelsea, St. Thomas's, Guy's, St. Bartholomew's, and the London Infirmary in Charterhouse Square. The patients generally required help from the overseers over and above the scales drawn up by the hospital governors. The Coggeshall authorities paid $19 \mathrm{~s}$. for incidental expenses to convey a woman to St. Thomas's in 1744. These included coach hire, fees for admission, payment to the ward sister, the porter, and the chairman, and the costs of staying at an inn. The parish of Theydon Garnon kept a woman patient at Guy's for sixty-three days at a cost of £1 $11 s$. $6 \mathrm{~d}$. plus various bills for washing and transport. 17

Medical historians have been strongly sceptical about the effects on mortality of

13 BRO, D/P 38/8; A. F. J. Brown, English history from Essex sources 1750-1900, Chelmsford, County Council of Essex, 1952, p. 142.

${ }_{14}$ T. McKeown and R. G. Brown, 'Medical evidence related to English population change in the eighteenth century', in D. V. Glass and D. E. C. Eversley (editors), Population in history, London, E. Arnold, 1965 , p. 291.

15 BRO, D/P 2/18/7; BL, MS.D.D.Par. Henley b.1. Winchester parishes paid subscriptions to the hospital in the city: L. F. C. Pack, 'A study of the evolution of the methods of poor relief in the Winchester area, 1720$1845^{\prime}$, unpublished M.A. thesis, University of Southampton, 1967, pp. 177-178.

16 BL, MS.D.D.Par. Wheatley, b.6, b.7; MS.D.D.Par. Culham, b.6.

17 ERO, D/P 36/13/12; 152/18/6. Devon parishes used the Devon and Exeter Hospital, the Exeter Infirmary, the Deaf and Dumb Institution, the Dispensary for the Sick Poor, and the Private Asylum. The Plymouth Eye Infirmary was also used: J. S. Taylor, 'Poverty in rural Devon', unpublished Ph.D. thesis, University of Stanford, 1966, pp. 89, 90, 91, 198, 239, 280-281. Cf. G. W. Oxley, Poor relief in England and Wales, 1601-1834, Newton Abbot, David \& Charles, 1974, pp. 68 and 131-132, n.25. 


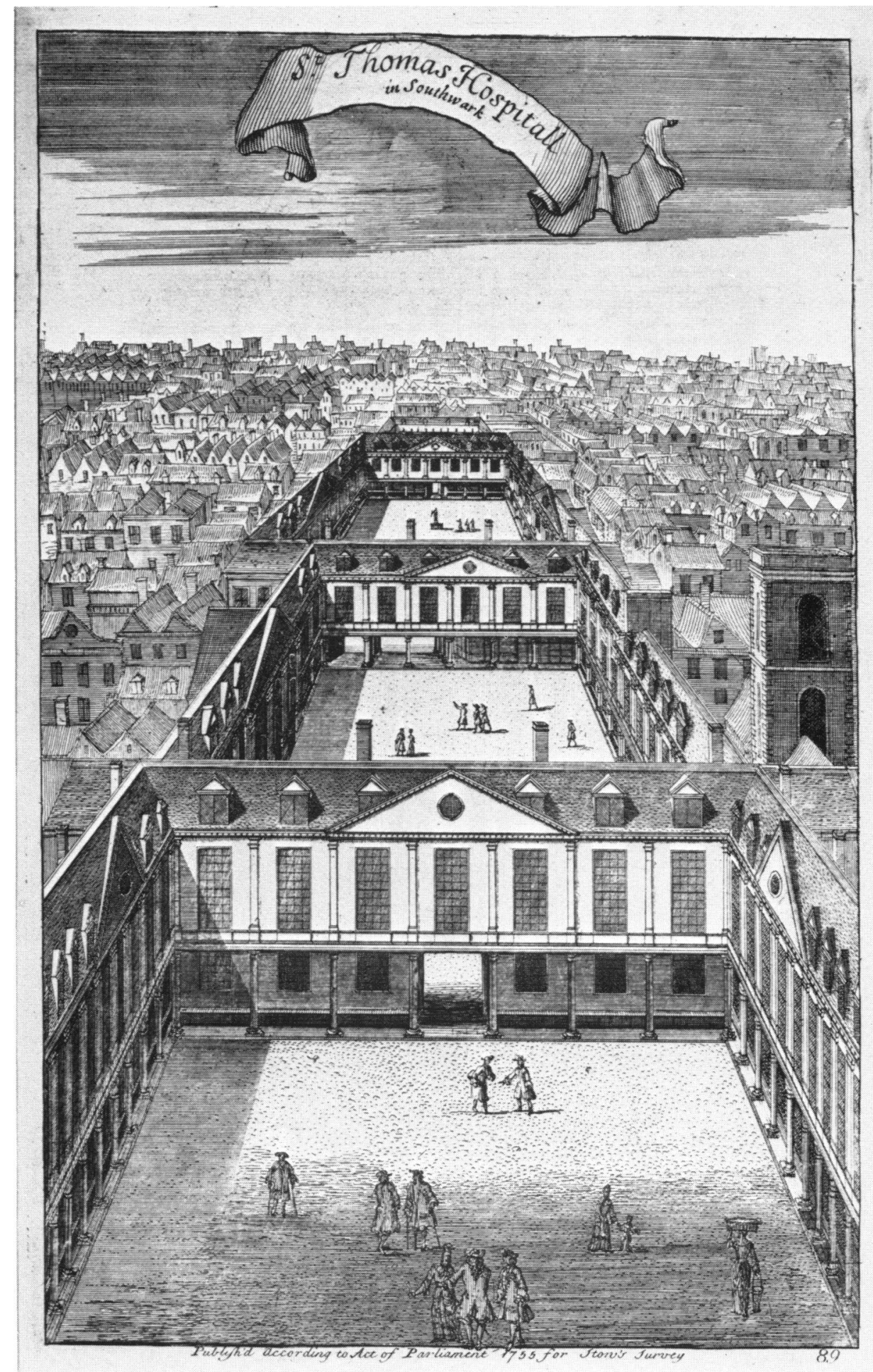

Figure 1.

St. Thomas's Hospital, Southwark. From a line-engraving published in 1755 for Stow's Survey. (Reproduced by courtesy of the Wellcome Trustees. ) 


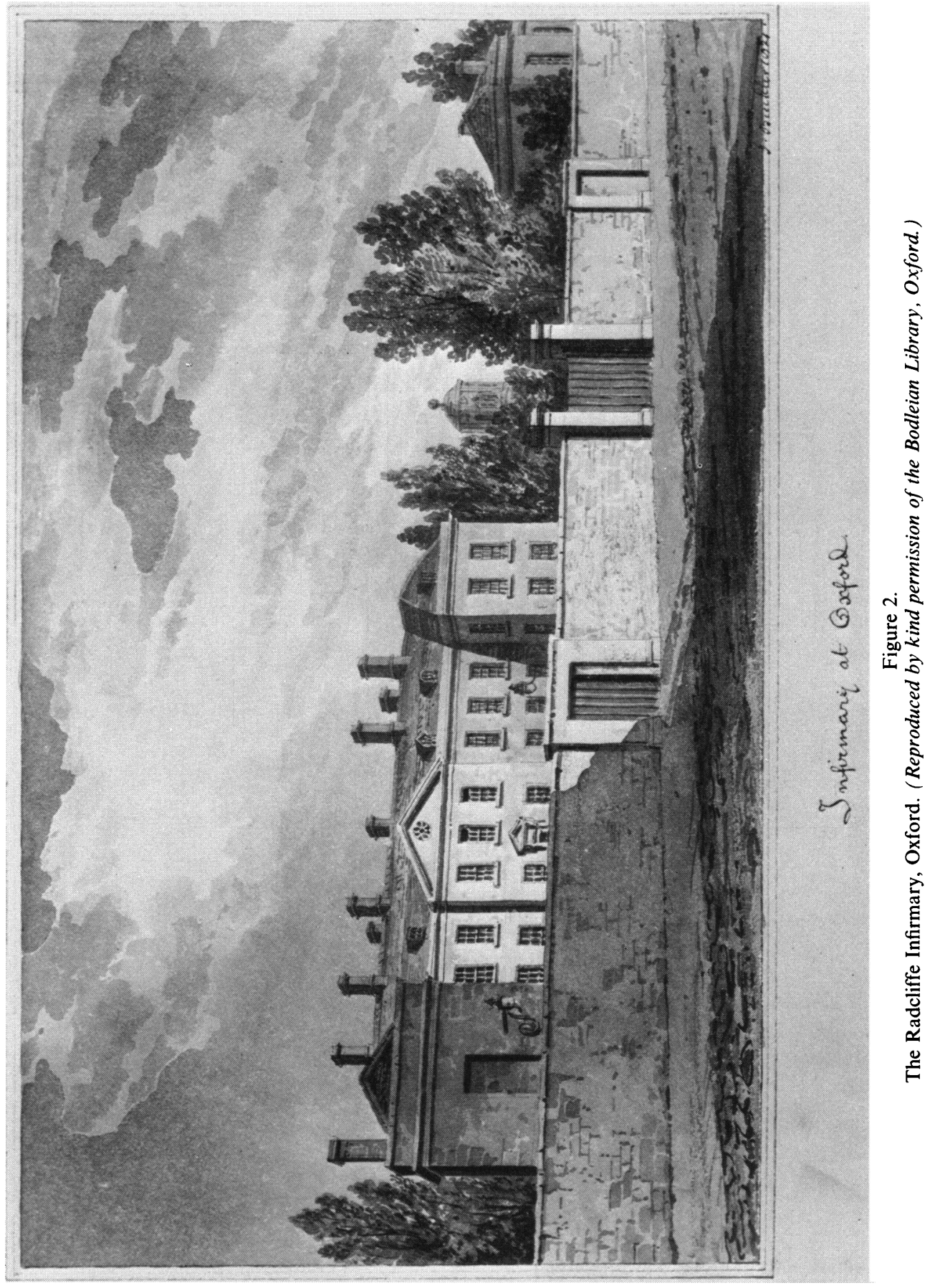




\section{The old poor law and medicine}

eighteenth-century medicine. The view of McKeown and Brown was that the increase in the provision of hospitals was likely to have increased mortality - they "positively did harm". ${ }^{18}$ However, more recently their views have been challenged on the grounds that they exaggerated the mortality and underestimated the extent to which segregation was practised in the eighteenth-century institutions. ${ }^{19}$ A study of the York County Hospital has shown mortality rates of between 3 and 6.3 per cent for inpatients at selected periods - rather lower figures than McKeown and Brown suggested. The York Hospital discharged 90 per cent of its patients as "cured or relieved" between 1740-83 and 89.5 per cent between 1784-1842. Although these descriptions might be misleading, the institution does not seem positively to have increased mortality. 20

With regard to the practice of segregation, some provincial hospitals did exclude infectious diseases. Thus Shrewsbury excluded smallpox patients in 1747, and Leeds did so in 1767. By 1816, York was segregating its fever cases and as early as 1755 had excluded venereal disease. ${ }^{21}$ The Radcliffe Hospital in Oxford excluded poor persons from the workhouses "lest they bring infectious disorders", and from 1802 it also excluded pregnant women, children under seven, lunatics, and "cases of fits, smallpox, scrophulous, ulcers, cancers, consumption, dropsies etc." 22 The figures given in the Radcliffe Report for 1829-30 are 408 in-patients "cured" out of 932 and 176 outpatients "cured" out of 354. Of course, the word "cured" must be treated with some caution, but certainly the Radcliffe patients did not "normally" die there. Such figures do not really prove that the hospitals made a positive contribution to the reduction of mortality, but institutions like the Radcliffe do not appear to have assisted its increase. Conditions in respect of fresh air and cleanliness might have been an improvement on a pauper's home. Many patients were admitted for rest and attendance rather than an operation or a definite course of treatment. At Oxford, for instance, some patients were fit enough to carry coals to the ward, to work in the laundry, and to attend the water engine. 23

18 McKeown and Brown, op. cit., note 14 above, p. 125; cf. Phyllis Deane, The first industrial revolution, Cambridge University Press, 1965, p. 29, "People who went to hospital in the eighteenth century normally died there, generally from disease other than that with which they were admitted." K. F. Helleiner refers to the hospitals as "gateways to death": 'The vital revolution considered', in Glass and Eversley (editors), op. cit., note 14 above, p. 84 .

19 M. W. Flinn, British population growth, 1700-1850, London, Macmillan, 1970, p. 43.

20 E. Sigsworth, 'A provincial hospital in the eighteenth and early nineteenth centuries', College of General Practioners' Yorkshire Faculty Journal, June 1966, p. 4.

21 W. B. Howie, 'The administration of an eighteenth-century provincial hospital: the Royal Salop Infirmary 1747-1830', Med. Hist., 1961, 5: 34-55; S. T. Anning, The General Infirmary at Leeds, 2 vols., Edinburgh, Livingstone, 1963-66, vol. 1, p.8; Flinn, op. cit., note 19 above, p. 6, n.4; Sigsworth, op. cit., note 20 above, p. 7, n.3.

22 BRO, D/P 2/18/7; A. G. Gibson, The Radcliffe Infirmary, Oxford University Press, 1926, p. 195. In 1777 a woman supposed to be suffering from dropsy gave birth at the Radcliffe: Oxford Journal, 13 December, quoted by Woodward, op. cit., note 11 above, p. 52. Obviously it was impossible to diagnose all cases, and pregnant women seem often to have eluded the authorities. Howard strongly criticized the Radcliffe for its "closeness and offensiveness", though one of the physicians defended it, describing it as "remarkably free from contagious fevers". He maintained that fevers had been introduced "inadvertently" but had "seldom spread": Woodward, ibid., p. 102. There were no isolated fever wards until 1824; until that date a patient who contracted a contagious disease was removed to one of the pest houses in the House of Industry: Gibson, op. cit., p. 39.

23 Gibson, ibid., p. 195. 


\section{E. G. Thomas}

The hospitals of the eighteenth and early nineteenth centuries obviously left much to be desired, but they continued to increase in numbers and patients appear willing to have entered them. Certainly parish authorities made every effort to utilize such facilities as they provided and were prepared to spend considerable sums of money on what they regarded as necessary and beneficial for the sick poor in their care.

\section{THE MENTALLY DEFECTIVE}

Of mental disability the parish obviously had to take notice. Elizabethan legislation had made no separate provision for this type of pauper and it was not until 1714 that a distinction was made between pauper lunatics and "Rogues, Vagabonds, Sturdy Beggars and Vagrants". ${ }^{4}$ If there were relatives, the responsibility fell on them; failing this, unqualified people might be asked to deal with the lunatic and be paid by the overseer. This system of boarding out appears to be the origin of the private madhouse. 25 Eighteenth-century workhouses and Houses of Correction also contained numbers of pauper lunatics.

The treatment by the parish officers was generally only of a physical kind but there was little else that could be done locally. If the parish case was fairly harmless, overseers gave allowances - as at Woodford where Matthew Finkle was given $2 s .6 d$. "for the maintenance of his idiot son, provided he employs a proper person to look after him". It was impossible to deal with the more violent cases and the parishioners looked to the authorities for protection. At Tilbury the overseers reported that a parishioner "is so far disordered in his senses that it is dangerous for him to be permitted to go abroad", and the local Justice ordered that he be locked up in the workhouse and chained if necessary. A Colchester parish paid for a "strait waistcoat" to enable a patient to be sent to Bedlam, whilst at Ashbury in Berkshire some local inhabitants were paid "to help chain Mary Hays". ${ }^{26}$

Contracting out became the accepted policy for "acutely disturbed" or "refractory" cases. Hence the growth of private institutions, many of which catered solely for paupers. By 1807 there were fifty establishments, the largest of which were at Bethnal Green, Edmonton, and Hoxton. Parishes took advantage of these private institutions such as Hook Norton and Witney in Oxfordshire, and High Beech, Plaistow, Hoxton, and Bethnal Green in the case of Essex. The Cuddesdon overseers in Oxfordshire transferred a parishioner from St. Luke's to Mr. Talbot's Institution at Bethnal Green. Great Tew in the same county used this establishment as did the Berkshire parish of White Waltham. Fees were high $-£ 26$ a year at Bethnal Green in the 1820s.27

In Essex the Chelmsford authorities kept a patient at Plaistow for a year at $9 \mathrm{~s}$. a week. The asylum governors circulated a handbill in 1825 praising the amenities of their institution: "This house is spacious and commodious with extensive Grounds and Walled Gardens, and from its healthy and retired situation is calculated to admit

2412 Anne, C.23.

25 W. Ll. Parry-Jones, The trade in lunacy, London, Routledge \& Kegan Paul, 1972, p. 7.

26 Erith, op. cit., note 7 above, p. 56; ERO, D/P 91/12; 177/13/5; BRO, D/P 9/12/2.

27 Cuddesdon parish chest, overseers' accounts; BL, MS.D.D.Par. Great Tew, b.2; BRO, D/P 142/12/2. The Berkshire parish of Warfield used Hoxton in 1802: BRO, D/P 144/12/4; I am indebted to Mrs. D. Clanchy of Ascot for this reference. 


\section{The old poor law and medicine}

patients of every denomination." 28 This was probably a superlative description, but it is possible that mentally deranged paupers were better cared for - relatively - in an establishment of this type than if they remained in the local workhouse.

This aspect of medical attention was a very expensive item. The Dorchester overseers' accounts provide the best description of a case and the expenses and trouble involved. In 1746 attempts were made to get a woman into Bethlem. Her affliction was serious by 1759 and payments were made for "watching her" and "for bleeding". "A penny slip and a tape to bind Anne Hotchman" was an additional entry. Anne was finally taken to Bethlem at a cost of five guineas; she was transferred to St. Luke's in 1761, and was at Hoxton from 1762-63. She entered the incurable side of Bethlem in 1763, and annual payments are recorded until 1783. The total cost to Dorchester approached $£ 225$. At Great Milton, also in Oxfordshire, the overseer paid $£ 128$ s. $6 d$. merely for the journey and entry to St. Luke's. ${ }^{29}$

In Oxfordshire itself parishes had access to the institutions at Hook Norton and Witney. Hook Norton was established in the early eighteenth century and operated on a small scale until it expanded in the 1830s. Paupers formed seventy-five per cent of the admissions. The cures effected amongst them were less than private patients; the small group of incurables were almost all paupers. The Witney establishment was founded in 1823 and only took a very small number of paupers and, after 1832, none. ${ }^{30}$

As the Oxford Lunatic Asylum was not built until 1826 and there was no pauper asylum until 1846, the private institutions met a real need at a time when public provision was slow in emerging. Both Hook Norton and Witney appear to have been satisfactory establishments, and there is no evidence of any outstanding shortcomings. On the contrary, the proprietors of both institutions belonged to well-known local professional families who organized their houses with humanity and integrity. ${ }^{31}$

\section{MEDICAL CONTRACTS}

Personal medical attention in every case was impossible - especially in the larger parishes and particularly when population was on the increase. Thus from the 1740s parishes found it more convenient, and probably less expensive, to contract with a doctor for medical attention based on a lump sum. The great proportion of contracts date from the late eighteenth and early nineteenth centuries when it was likely that the pressure of population really made itself felt. With the contract system the individual approach noticeable in early years is less in evidence.

The form of contract in the three counties was much the same. It often excluded expensive items like smallpox and midwifery, though inclusive agreements were sometimes negotiated. Occasionally a group of parishes combined to avail themselves

28 ERO, D/P 94/18.

29 Dorchester parish chest, overseers' accounts; see also, E. G. Thomas, Victoria county history: Oxfordshire, vol. 7, pp. 51-52; Great Milton parish chest, overseers' accounts. For a parishioner looked after for sixteen years see G. C. Edmonds, 'Accounts of eighteenth-century overseers of the poor of Chalfont St. Peter', Records of Buckinghamshire, 1966, 18: part I, 14-16.

30 Parry-Jones, op. cit., note 25 above, pp. 141, 285-286; table 7, p. 45; table 17, p. 159. Berkshire also used Hook Norton and Witney.

31 Ibid., pp. 148-149, 285. In 1829, of 177 pauper lunatics in Oxfordshire 17 were in public asylums, 20 in private institutions, and 140 at large or with relatives: ibid., table 15, p. 130. 


\section{E. G. Thomas}

of medical facilities. There was, of course, keen competition to secure these contracts and often doctors undercut each other in their fees. Alternatively, a rota system might be arranged.

At Chelmsford in 1747 five doctors attended the poor within an area of two miles and, on the Essex coast, at Great Wakering, a surgeon agreed to visit the small islands within the parish boundaries. In North Oxfordshire, at Deddington, ten surrounding parishes were included in a medical contract. Such a union of parishes was particularly useful in rural areas where the inhabitants were widely dispersed and where parishes could share the cost. Some doctors insisted on a sliding scale of charges on mileage. Thus at Chelmsford additional costs for visits outside the town were added to the overseers' bill of $£ 50$ a year. 32

In the nineteenth century salaries for doctors were often as high as $£ 50$ in the towns. Where low salaries were negotiated on a competitive basis the poor were likely to have suffered. In fact, at Woodford in Essex, doctors were undercutting each other for a contract price. In 1779 the parish officers accepted $£ 8$, but in 1780 they received a number of complaints from the poor, which after investigation were found to be justified. A churchwarden met the Woodford doctors, subsequently, and it was agreed that there were some grounds for complaint, although it was impossible to give better treatment at the price. Thereafter, the local doctors worked on a rota system at a twelve-guinea fee. 33 The continually increasing fees for doctors represented part of the burden parish overseers had to bear in a time of increasing costs for most necessities. Thus the fee of four or five guineas in the mid-eighteenth century reached fifty or sixty guineas by the early nineteenth century.

\section{SMALLPOX}

Smallpox was the greatest scourge with which the parishes had to deal and was a constant drain on the poor rates. Prior to inoculation, overseers did the best they could in the way of treatment by cleaning the premises, providing food, and giving allowances, and there were also attempts at isolation in the pest-houses. Costs were heavy. Dorchester paid $£ 9$ out of a total expenditure of $£ 90$ in 1741 , and the doctor received $£ 10$ for treating an outbreak in 1750 . In 1774 expenses were $£ 18$ out of a total of $£ 96.34$ Parish accounts provide considerable detail about individual cases. One at Ashbury in Berkshire in 1790 involved payments for cleaning the house; milk and oatmeal; a journey to the doctor's and to the pest-house at Highworth, Wiltshire, (six miles), with costs there. The final bill was $£ 147 \mathrm{~s}$. $0 \mathrm{~d}$. three months after the illness began. At Burford, after a severe epidemic in 1758 in which 185 people died in four months, $£ 20$ was expended "for six days work cleaning beds"; "for 21 bushels of lime"; "for whitewashing"; and "for 85 pairs of shoes".35

32 ERO, D/P 94/5/2, 194/12/1; Deddington parish chest, vestry minutes, 1824; ERO, D/P 94/12/15.

33 Erith, op. cit., note 7 above, p. 53; cf. the doctor at Corfe Castle who was paid $£ 20$ in 1802 and who maintained he "could not act justly to the poor or myself on these terms": G. Body, "The Poor Law in Dorsetshire 1760-1834', unpublished Ph.D. thesis, University of Southampton, 1964, p.194.

34 Dorchester parish chest, overseers' accounts.

35 BRO, D/P 9/12/2; Burford parish chest, overseers' accounts. At Dedham in north Essex, of 339 cases of smallpox 106 were fatal, whilst at Chelmsford of 290 cases 95 died: P. E. Razzell, The conquest of smallpox, Firle, Sussex, Caliban Books, 1977, pp. 131, 132. 


\section{The old poor law and medicine}

Banbury experienced a severe outbreak in 1769 and final costs were $£ 106$ that year. The expenses included: "For hedging and fetching hurdles thornes and stakes to mound in the small pox $3 s$. For the pit being dug for the smallpox $6 d$. Pd for lime and whitewashing the smallpox houses 3/6d." A smallpox house was set up and doctors and nurses employed. The Banbury authorities had been fortunate during an earlier epidemic in 1753 when $£ 78$ 15s. had been sent by the Lords Guildford, Godolphin, and Wallingford for the relief of the distressed families. An additional poor rate levy would certainly have been needed without this gift. The town of Bicester also contributed ten guineas and "the worshipfull James Wast" $£ 20$. Lord Guildford also gave a further $£ 10$ at Christmas. 36

Isolation was obviously essential in a smallpox epidemic and parish authorities often made strenuous attempts to build a pesthouse or adapt a building for that purpose. These were early public health measures, in effect, to try to prevent the spread of the disease. The parish of Coggeshall in Essex built an isolation house in 1759, land being bought at the far end of the parish right away from the road. Woodford built one in Epping Forest and, when not in use to house infectious parishioners, it was used as an ordinary poor house. In Oxfordshire the Culham overseers went to Abingdon four times in 1779 "to get a place for the people with small pox" whilst at Banbury in 1743 the overseers were given power to take the castle for the pest-house "or any other convenient house if that cannot be obtained." Burford used a barn in 1805, and paid its owner compensation for any damage done during its use. ${ }^{37}$ This increasing use of isolation buildings might well have been a contributory factor in the reduction of the spread of a smallpox outbreak.

\section{INOCULATION}

In 1721 the practice of inoculation was introduced into England when Lady Mary Wortley Montagu had her daughter treated. Its application was limited in the $1720 \mathrm{~s}$ and 1730s mainly because the technique proved costly and fatal in a number of cases. In the 1740s the practice was revived with the development of a milder treatment, though the procedure was more complex and expensive. In 1763 Lewis Paul Williams of Leicestershire achieved a more simplified process, and the Sutton family, also in the $1760 \mathrm{~s}$, developed a technique of injecting the minimal amount of virus with only a small scratch. The Suttons claimed to have inoculated 55,000 people between 1760 and 1768 , of whom only six died, and, by 1776, 300,000 people. They offered free inoculation to the rural poor if the rest of the parish were treated. Daniel Sutton for instance, inoculated 417 poor people in one day in Maldon, Essex, none of whom died. 38

McKeown and Brown, whilst admitting that smallpox was the one positive disease which might have been reduced by preventative therapy, nevertheless found it difficult to believe that inoculation was responsible for a large enough reduction of smallpox

36 Banbury Borough Library, Banbury vestry minutes.

37 ERO, D/P 36/12; Erith, op. cit., note 7 above, p. 54; BL, MS. D.D.Par. Culham b.5; Banbury Borough Library, vestry minutes; Burford parish chest, vestry minutes.

38 P. E. Razzell, 'Population change in eighteenth-century England. A reinterpretation', Econ. Hist. Re''., 2nd series, 1965, 18: 317-318; For the Suttons, see D. Van Zwanenberg, 'The Suttons and the business of inoculation', Med. Hist. , 1978, 22: 71-82. 


\section{E. G. Thomas}

significantly to have affected mortality rates. ${ }^{39}$ This is a viewpoint which has, however, been recently challenged. It has been suggested that smallpox was so significantly a cause of death and inoculation so effective in controlling the disease that the treatment might have contributed significantly to the decrease in mortality in the eighteenth century. .40

Certainly from the 1760 s the parish records of the three counties frequently mention payments for inoculation - either of single persons, or families, or of the mass of the poor population. It was clearly a popular expedient in the rural areas and was also adopted by the smaller towns - Chelmsford in Essex, for instance, Hungerford in Berkshire, and Banbury and Henley in Oxfordshire, though the city of Oxford in 1790 banned it. The popularity of inoculation lasted until about 1810-11, and there was considerable overlapping with vaccination treatment from about 1806.

The earliest reference to inoculation in Oxfordshire is at Banbury in 1760 following a serious epidemic in 1759: "It was agreed that all Persons who belong to the sd borough shall if willing, receive the benefit of being inoculated and physick at the Expense of the Parish bearing all other Expenses themselves unless the Vestry should think proper to allow them any Assistance they may theink they should stand in need off." As a result 120 were inoculated at the town's expense. 41

The Vestry Minutes of Henley give perhaps the best evidence of the campaign against smallpox. In 1788 several persons were victims and it was decided: "Forthwith to inoculate such persons in the said Town being parishioners as are not able to bear the expense themselves at the expense of the Parish. And the Overseers are requested to apply to the several parish officers who have parishioners residing in this town and who have not had the smallpox to inoculate such poor persons forthwith. And Mr. Pope, $\mathrm{Mr}$. Coulson and Mr. Bealey being present agreed to inoculate such persons and give them proper attendance and Physick at five shillings a person." 42 Such references are numerous in Oxfordshire and particularly in rural areas the practice of inoculation appears to have been very popular. 43

The authorities of the Berkshire town of Hungerford used the treatment, and the Vestry Minutes provide some statistical evidence of the success of mass inoculation of the poor: "In the latter end of July of this year 1794 the small pox was brought into this town by a Regiment from Ireland. One soldier died of a very violent sort in the Pest House. The Disease, spreading among the inhabitants, few of which had had it, a

\footnotetext{
39 McKeown and Brown, op. cit., note 14 above, p. 292; Creighton's opinion was that "the ordinary course of smallpox was little touched by inoculation" (C. Creighton, A history of epidemics in Britain 16661893, 2 vols., Cambridge University Press, 1891-94, vol. 2, p. 516).

40 P. E. Razzell, 'Population growth and economic change in eighteenth- and early nineteenth-century England and Ireland', in E. L. Jones and G. E. Mingay (editors), Land, labour and population in the industrial revolution, London, E. Arnold, 1967, p. 263.

41 Banbury vestry minutes; Razzell, op. cit., note 35 above, pp. 57, 68, cites earlier instances of mass inoculation at Beaminster 1758, Salisbury 1753, Bradford-on-Avon 1752-53, and Blandford in 1753. At Winchester 900 were inoculated in 1774 including nearly 400 paupers: W. H. Boorman, 'Smallpox in eighteenth-century Winchester', Local Population Studies Magazine and Newsletter, 1968, 1: 37. Pack, op. cit., note 15 above, p. 176, refers to the Winchester poor being inoculated as early as 1733 .

42 BL, MS.D.D. Par. Henley, b.1.

43 E.g., Shiplake 1784, 1804; Culham 1790, 1799-1800; Hook Norton 1794; Cowley 1805, 1806; Kidlington 1788, 1806; Yarnton 1794; Wheatley 1804; Pyrton 1806; Dorçhester 1789, 1794 and 1799; and Stadhampton 1801 .
} 


\section{The old poor law and medicine}

vestry was held to determine on the necessity of immediately inoculating the Poor of the parish, when it was determined to employ Mr. Cundell for that purpose at $2 / 6 d$. per head. Of this description above one thousand, of all ages, received the infection, not above two or three of which number died. About 20 perished with the natural sort." 44

The practice was occasionally regarded with suspicion. At Wantage in 1754 the authorities tried to prevent the inoculation of "inmates or lodgers" though, in fact, forty-one people died of smallpox that year. ${ }^{45}$ However, in Berkshire, examples of inoculations are frequent from the $1770 \mathrm{~s} .46$

In Essex the picture is similar. Inoculation became popular in the 1750 s and in 1753 it was claimed that "the lower class of people were coming to it very fast" in the Chelmsford area. Between 1765 and 1767 15,000 were treated within fifty miles of Chelmsford, not one of whom died. There were slight symptoms - a little sickness - but no scars or pits. Mass treatment was provided at Maldon in 1764, 1767, 1779, 1788, 1799 , and 1806.47

There is evidence that there was suspicion of inoculation in some Essex parishes especially when smallpox was not prevalent. At Great Sampford the vestry warned the overseer that. if he inoculated any of the poor without consent they would not grant a rate to cover the expenses involved. At the Woodford vestry meeting of 1795 , at which a leading doctor and justice was present, a parishioner was ordered not to inoculate one of his children - "if you persist in such a Measure, the smallpox not being in this Parish, we will immediately take such steps against you as the law warrants." 48

Bearing in mind that some parishes objected to inoculation and that others probably treated the population too infrequently, there must have been some effect on mortality trends as a result of the extensive spread of inoculation from the 1760s in the three counties under consideration. The fact that 1,000 were inoculated at Hungerford, for example, must have meant a considerable saving in lives. Of the twenty-three who died, twenty did not undergo treatment - probably they had objected or had contracted smallpox before the campaign got underway.

Contemporary writers certainly thought that the extensive spread of inoculation must have had a significant effect. Howlett's opinion was that: "the diminished mortality ... of provincial towns and villages . . . appears chiefly owing to the salutary practice of inoculation . . . where two or three hundred used to be carried to

44 BRO, D/P 71/8/1. George Pearson, An inquiry concerning the history of the cow pox, London, T. Johnson, 1798 , p. 79 , refers to the Hungerford inoculation, and his figures are 800 treated without a single death: P. E. Razzell, 'Edward Jenner: the history of a medical myth', Med. Hist. , 1965, 10: 227. Cf. the 126 poor persons inoculated at Harlington in Bedfordshire in 1788, two of whom "fell in the natural way": $P$. Grey, The Old Poor Law, Bedfordshire Archive Teaching Unit, no. 1, 1972.

45 BRO, D/P 143/12/1.

46 E.g., at Tilehurst 1779; Bray 1794; Ardington 1795; Sparsholt 1801; East Hendred 1806; Shinfield 1806; Drayton 1810; and White Waltham 1811.

47 Gentleman's Mag. , 1753, 23: 217; Razzell, op cit., note 35 above, pp. 52, 62, 86; Inoculation made easy. Containing a full and true discovery of the method practised in the County of Essex, 1767; Maldon All Saints' Registers. A doctor in Castle Hedingham between 1763 and 1767 inoculated "thousands": Brown, op. cit., note 10 above, p. 141. Other mass inoculations in Essex took place at Wickford 1796, 1811, 1821, 1827; Rayne 1806; Great Chishall 1788; Canewdon 1799; Leyton 1797, 1801 ; Witham 1779 (1000 in one week); and Mistley 1773.

48 ERO, D/P 289/8/2; Erith, op. cit., note 7 above, p. 55. Wimborne in Dorset opposed inoculation in 1786 and Studland in 1826: Body, op. cit., note 33 above, p. 195. 


\section{E. G. Thomas}

their graves in the course of a few months, there are now perhaps not above twenty or thirty."49

\section{VACCINATION}

It is unlikely, however, that inoculation was the only factor and, if specific preventative therapy is to be taken into account as a possible contributory measure, Jennerian vaccination probably played a significant part in reducing smallpox deaths. Following Jenner's discovery in 1798, parishes gradually adopted the new procedure in the early nineteenth century. Some continued with inoculation; others practised both. The earliest reference in the three counties is at Tilehurst in Berkshire in 1802, though it was from about 1806 that vaccination became popular. Constant references then occur until the 1830s. Mass treatment of the poor was frequent, the expense either being covered out of the poor rates or by a special parochial contribution. Towns like Henley, Hungerford, Woodstock, Burford, Coggeshall, and Chelmsford became aware of the efficacy of the new treatment and organized campaigns for mass vaccination; on occasion compulsion was used - as at Hungerford.

The earliest references in Oxfordshire are at Pyrton and Witney in 1806. At Pyrton vaccine was provided for the whole parish and in 1818 seventy-three more people were treated. At Witney the surgeon was to attend and "inoculate the poor in the vaccine method without any additional charge" though the overseer paid out $£ 10$ finally. 50

The Henley authorities by 1810 were well aware of the possibilities of vaccination as they had been of inoculation in 1788 - though they faced a conservative attitude towards the new method: "At this Vestry it was reported by the present overseers that in consequence of several families in this parish having taken the smallpox they have made a general inquiry of poor families whether in case of a General Inoculation they were willing to have the Cow Pox; about one third only were willing to have it. In consideration of this report it was proposed whether those families who refused the Cow Pox should be offered to be inoculated with the smallpox which was agreed to." A handbill was sent to each of the families to whom this offer was made and they were given a few days to avail themselves of it. By 1818 the vestry had decided on a general vaccination: "Unanimously resolved that a general vaccination do immediately take place through this Town and Parish of such poor persons as are willing to have themselves or children vaccinated; and they are hereby requested to call upon the Churchwardens and Overseers for that purpose . . . We the undersigned medical men are decidely of opinion that Cow-Pock is not only a safe and effectual Preventative of Small Pox, but free from all its loathsome and dangerous consequences." This latter statement was signed by five doctors. The Henley campaign continued in 1820,1823 , 1826 , and 1831.51

49 Rev. John Howlett, An examination of Dr. Price's essay on the population of England and Wales. . . , Maidstone, 1781, p. 83n, quoted by Razzell, op. cit., note 35 above, p. 152. Howlett was vicar of Great Dunmow, Essex. At Bradford, Devon, the large numbers of poor inoculated in the 1790s might have helped to achieve the appreciable decrease of infant mortality in the early years of the next century: Taylor, op. cit., note 17 above, pp. 198-199.

50 BL, MS.D.D.Par. Pyrton, c.5; Witney parish chest, vestry minutes.

51 BL, MS. D.D. Par. Henley, b.1, b.2. There are numerous other references in Oxfordshire, e.g. Yarnton 1816; Culham and Dorchester 1812; Cropredy 1811; Wheatley 1817; Watlington 1825; Shennington 1826; Burford 1829; and Deddington 1830. 


\section{The old poor law and medicine}

The view of the parish authorities in Tilehurst, Berkshire, in 1802 was: "That on due consideration we think Inoculation by the Cow-Pock preferable to the Small Pock we being assured by Mr. Golding that it is equally efficacious as a preventative of the small pox and will be attended with much less inconvenience, not being contagious; and also with much less expense to the Parish, which by adopting that method will be relieved from many difficulties. That we agree to inoculate with the Cow Pock at their respective homes such of the Parish Poor as are willing to have it at the expense of the Parish." Two points emerge here. One that vaccination was considered less contagious - inoculation was often known to spread smallpox to susceptible persons, though the Suttonian technique did produce a milder type of infection. Second, vaccination was cheaper - a fact which would appeal to all parochial authorities. At Tilehurst $\mathrm{Mr}$. Golding was to be paid $5 s$. per head and the treatment was to be confined to the poor parishioners of Tilehurst only. By 1804 no person could receive vaccination unless he received an order from the overseer. 52

Mr. Golding was a Reading practitioner and his treatment was sought by the parish of Shinfield in 1806. The vestry consulted him on the relative efficacy of inoculation and vaccination - "if he is of the opinion that inoculation with the cow pox is a sufficient preservative against the small pox that he inoculates them [the poor families] therewith. Should he not be of that opinion - then, that he inoculates them with the small pox." There is no further evidence until 1814 when a "General Inoculation" took place at $5 s$. per head. ${ }^{53}$ This is likely to have been vaccination in view of Mr. Golding's view expressed at Tilehurst.

Economy and convenience led parishes to adopt compulsory vaccination, as at Hungerford where inoculation had also been compulsory. In 1811 it was: "Resolved that it is the opinion of this Meeting that the vaccination from the Cow Pox has in general been found more effectual than the inoculation from the natural small pox and that it be earnestly recommended to the Inhabitants of this Parish to pursue that Method as having been found to be very mild and lenient in its Effects and perfectly capable of superseding the violent and dangerous Effects arising from the natural Small Pox .... Resolved that in case any poor person shall refuse to use the vaccine inoculation and afterwards be taken ill of the small pox in the natural way or by inoculation that they will in such case be removed to the Pest House." In 1824 the vestry took an even stronger line and decided that all paupers who refused to attend with their children and themselves to be vaccinated should not receive any relief from the parish officer - an order repeated in 1831.54

Inoculation did not disappear with the development of vaccination and appears to have remained popular with the poorer classes. Thus both techniques continued for some time and numbers of people must have been treated with both. At Drayton in Berkshire in 1810 all the poor were inoculated with smallpox "except some with cow

52 BRO, D/P 132/8/1, 2. The next earliest example of vaccination found was in 1803 at Castle Hedingham in north Essex. Cf. the free vaccinations provided by a Nottingham doctor in 1800: J. D. Chambers, 'Population change in a provincial town 1700-1800', in Glass and Eversley (editors), op. cit., note 14 above, p. 348, n.43.

53 BRO, D/P 110/8/1.

54 BRO, D/P 71/8/1, 3, 5. Other vaccinations took place at Wantage 1806; East Hendred 1807; Cumnor 1815; Wokingham 1825; Cholsey 1833; and Ufton Nervet 1833. 


\section{E. G. Thomas}

pox"; whilst Cumnor treated a total of ninety-two people in 1815, twenty of whom were given permission to be inoculated. 55

At Wickford, in Essex, both techniques were used until 1827. In 1811 thirty-four children were inoculated and seven vaccinated; in 1821 of fifty-one children treated forty-eight were inoculated, and in 1827 thirty-four were inoculated out of forty-four. The doctors at Coggeshall in 1815 who were chosen "to use their best endeavours to vaccinate all the poor inhabitants", reported on their work and mentioned "a great disinclination to the cow-pox." The authorities were, however, convinced that it was "the mildest and a safe precaution" and urged the Doctors to continue their work. At Barking both techniques were offered in 1808 and in 1812.56

After about 1811, however, with very few exceptions like Wickford in Essex, parishes went over to vaccination. Towns like Chelmsford launched a campaign for greater preventative measures. After a smallpox outbreak in 1819 the overseers isolated all the children of the town in the pest-house and vaccination was ordered for all those in the workhouse and anyone else who wanted it. In 1821 the vestry maintained that the practice of vaccination had been "lamentably neglected in very many families resident in this parish". They were convinced of "the great utility of vaccination" and recommended the poor in particular to vaccinate without delay such of their children "as are still exposed to that loathsome and fatal disease." Again in 1829 the authorities urged treatment and were determined "to remove any prejudices which they may find to exist in the minds of their neighbours against vaccination which, although it will not always prevent the smallpox, yet in almost every instance mitigates its violence." An outbreak in 1829 resulted in twenty-three cases in five months but these recovered - probably due to the vaccination campaign. 57

Such vaccination campaigns by local authorities must have made some contribution to the reduction of mortality rates, though children made immune to smallpox were still exposed to other diseases. Treatment was, however, effective in preventing smallpox and even more effective in eliminating death from it. It was still at this period not universally adopted, and thus epidemics broke out, but it seems likely that many lives were saved by the parishes which took action. ${ }^{58}$ An alternative explanation of the reduction in smallpox deaths is a change in the nature of the disease at this time. However, as such a development would have taken place during the period of the

55 BRO, D/P 48/12/2; 45/18/4. The report of the National Vaccine Establishment, London, 1822, makes it clear that inoculation was still popular among the "lower orders of the people".

56 ERO, D/P 70/12/3, 4; 36/11/11; J. E. Oxley, Barking vestry minutes, Barking Borough Council, 1955 , p. 144. Woodford prohibited inoculation in 1828: Erith, op. cit., note 7 above, p. 55. Bampton, Devon, allowed parents to choose the treatment for their children as late as 1834: Taylor, op. cit., note 17 above, p. 92.

57 ERO, D/P 94/8/3. At Norwich in 18193,000 had smallpox, of whom 530 died. Vaccination had been neglected in the city for many years as parents were apathetic and it needed a great effort to get the children treated. See An address to parents on vaccination by a candid overseer, 1822.

58 Creighton, op. cit., note 39 above, p. 584, maintained that something approaching half the children born in London were vaccinated during the period 1800-1825; A. H. Gale, Epidemic diseases, edited by E. R. Hargreaves, Harmondsworth, Penguin Books, 1959, p. 64. Vaccination in the army and navy was very effective at this time, when fairly comprehensive treatment was possible. See The report of the National Vaccine Establishment, London, 1812, pp. 10, 168. At the Newcastle Infirmary 20,000 free vaccinations were provided in the first quarter of the nineteenth century: N. McCord, 'Aspects of the relief of poverty in early nineteenth-century Britain', in The long debate on poverty, London, Institute of Economic Affairs, 1972, p. 98. 


\section{The old poor law and medicine}

introduction of vaccination, the theory would be difficult to maintain.

\section{TYPHUS AND CHOLERA}

If therapeutic measures employed in the eighteenth century, preventative or curative, had a doubtful effect - smallpox treatment apart - on mortality trends, it is possible that the improvement of the environment had its effect on disease, particularly infectious disease. This understanding of the part played by environment was not due to a knowledge of infection but was derived empirically. Simple measures had been described in the early eighteenth century - better housing, ventilation, disinfection and control of nuisances.

Typhus and cholera created great problems for parochial authorities. Typhus was associated with war, but in the seventeenth and eighteenth centuries and the first half of the nineteenth century it was a frequent occurrence in London and in smaller towns. On the whole, deaths in the London Bills of Mortality slightly exceeded those from the smallpox. 59

Widespread starvation and infestation with body lice are necessary conditions for typhus, though an epidemic can spread throughout a community. It would certainly cause expenses for the overseers. In 1818-19, for instance, there were seventy typhus victims - all poor parishioners - in Hungerford. The overseers paid the parish doctor $£ 10$ above his salary for attending the poor and he did not lose one patient. 60

About 1818 cholera began to spread from India to Russia, the Middle East, the Balkans, and Germany. It reached Sunderland in October 1831. The infection was waterborne and conditions in towns were favourable to the disease, for much of the drinking water came from wells which were near cesspools, and piped water often came from rivers polluted by human sewage. ${ }^{61}$ By April 1832 the disease had spread to the south of England and is often mentioned in parish records. At Deddington in Oxfordshire it affected one-fifth of the resident paupers. Like typhus, it was the type of epidemic which would thrive in areas of sub-standard housing, especially where drainage was bad.

A temporary Board of Health had been set up in London in June 1831 and in October it advised the establishment of local boards consisting of the magistrates, clergymen, doctors, and other local representatives. Such Boards of Health were set up at Oxford, Henley, Reading, Hungerford, Chelmsford, and Barking. Hungerford, always to the forefront in public health legislation, drew up regulations in November for the cleanliness of houses and drains. Possibly the authorities there had some news of the epidemic in the north, for 500 handbills were printed and 200 more prepared at Bath. The town was divided into seven districts and an examination of cottages was made. The resultant report maintained that "all cottages were very much in want of drains at the back" and orders were given for existing drains to be cleaned and reopened and for dung-heaps and pig-sties to be removed further from the houses. Buildings were found generally to be in need of whitewashing.

At Reading all the parishes made combined efforts during the epidemic. A

59 Gale, op. cit., note 58 above, p. 74.

60 BRO, D/P 73/8/1.

61 Gale, op. cit., note 58 above, p. 67. 


\section{E. G. Thomas}

temporary cholera hospital was, in fact, erected, and beds, fuel, medicine, nurses, baths, and so on provided. Inspectors were ordered to visit and report on the state of all lodging houses kept for the reception of vagabonds. The town also organized a "house of observation" for those not affected but likely to have been in contact with the disease. The value of isolation, in other words, was beginning to be realized as an important preventative measure. 62

In November 1831 Barking - in co-operation with Ilford - set up a Board of Health in case cholera should appear. It was decided that any pauper applying for relief should be employed in cleaning courts and alleys and removing accumulations of filth, and bills were printed recommending the clearance of rubbish. Cholera, in fact, broke out in September 1832 and the workhouse was affected. Local people suggested that the food and general condition of the house were responsible and possibly that the epidemic started there. The Directors of the Poor inspected the building and in their report stated that they had particularly examined the food - especially the rice - and found it wholesome. There had been a report that the cooking coppers were in a dangerous condition owing to verdigris but the Directors found that only iron boilers were used in the workhouse. 63

The Minutes of the Chelmsford Board of Health indicate energetic and progressive attempts to improve the conditions of the poor in the town. A Board of twenty inhabitants was elected in November 1831 clearly as a result of the October outbreak of cholera in the north. Justices, clergy, doctors, and other leading inhabitants constituted the membership, and the town was divided into six districts each with a committee of six to eight people. Each group was responsible for examining drains, ditches, and privies, and for making reports on such "nuisances".

Within a fortnight it was clear that parts of Chelmsford were in an offensive condition. There was no system of sewers or drains in the hamlet of Moulsham for instance. Privies and dung-pits in various yards were considered dangerous to health. The common lodging houses for vagrants were thought to be a potential source of infection. By the end of November something had been done to improve the situation, but several owners of property proved unco-operative.

The problem was primarily the lack of facilities in the poorer homes. Each district committee was instructed to inspect such houses with a view to improving cleanliness and ventilation, and to the provision of adequate clothing and bedding. The Ladies' Benevolent Society were requested to inspect the homes of the female poor and to make a report on their needs. Many of the cottages of the poor were clearly insanitary and overcrowded. Some had two rooms, each of which only measured $8 \mathrm{ft}$. by $7 \frac{1}{2} \mathrm{ft}$. by $6 \frac{1}{2} \mathrm{ft}$; one row of houses had only one privy; other cottages had windows which were far too small. The poor could not afford to attend to their ditches, drains, and windows, nor did they have sufficient bedding in case of illness.

The Board decided to launch a fund in December 1831 and the response was quite generous. The Ladies' Society bought and distributed flannels, blankets, rugs, calico, sheeting, and bedding at a cost of $£ 14311 \mathrm{~s}$. $6 \mathrm{~d}$. Soup was also distributed and coal sold at a subsidized rate.

62 BRO, D/P 71/8/5; 96/8/2. At Oxford the eleven united parishes set up a Board of Health.

63 Oxley, op. cit., note 17 above, p. 253. 


\section{The old poor law and medicine}

In January five Chelmsford doctors issued a report on the precautions that ought to be taken in case cholera broke out in the town. They recommended the equipping of an isolation centre, a stock of medicines, the acquisition of apparatus for generating heat, and a continued inspection of premises. The gaol, house of correction, poor house, and almshouses were all considered as potential cholera hospitals and, finally, a part of the poor house was equipped. By February six warm air baths had been purchased; these consisted of a gauze wire safety lamp, the burner ignited with spirit of wine reputedly producing a temperature of $106^{\circ} \mathrm{F}$. These were inserted under the bedclothes which were raised by a cradle. A chest for medicines was also purchased and a covered vehicle acquired for transporting the sick.

Much had thus been attempted to prevent, or at least mitigate, the onset of cholera. The first six cases, however, occurred on $18 \mathrm{June} 1832$, and three of them proved fatal. Further inspections resulted and the houses of the poor were ordered to be whitewashed, the material being provided by the Board. Graves of cholera victims were to be dug two feet deeper and the overseer was to issue a pitched sheet for each victim. Further checks were made on the yards in the town and chloride of lime provided for each house in one particular area which had consistently been reported as unhealthy.

Further cases occurred until 1 September. The total number reached twenty-one and the deaths twelve. The Chelmsford doctors refused to make a charge for attendance on the cholera cases during this period, though they were subsequently given thirty guineas by the Board as a gesture for the services they tendered both amongst the cases and in committee work. ${ }^{64}$ The epidemic was not a serious one when compared with other cases. ${ }^{65}$ It is possible that the early and energetic action of the Chelmsford Board went some way to mitigating the effects of the outbreak.

\section{CONCLUSION}

Many historians agree that mortality was declining in the second half of the eighteenth century, though opinions have ranged widely over the possible factors making for such a decline. Medical advances have been amongst the possibilities put forward, but these have also largely been discounted subsequently. Hospitals, for instance, have come in for a fair degree of criticism. 66 However, recent evidence points to a more favourable picture of their achievements and the case against them appears to have been overstated.67

64 ERO, Chelmsford Board of Health minutes 1831-33, D/P 93/24/1; Brown, op. cit., note 10 above, pp. 96-97. For a detailed account, see E. G. Thomas, 'The Chelmsford Board of Health 1831-2', Essex Journal, 1976, 14-27.

65 E.g., 440 people died at Exeter: N. Longmate, Alive and well. Medicine and public health 1830 to the present day, Harmondsworth, Penguin Books, 1970, p. 30.

66 T. McKeown and R. G. Brown, 'Medical evidence related to English population changes in the eighteenth century', Population Studies, 1955, 9: 119-141; T. McKeown, R. G. Brown, and R. G. Record, 'An interpretation of the modern rise of population in Europe', ibid., 1972, 26: 345-382.

67 E.g., the Nottingham General Hospital between 1782 and 1814 claimed to have treated 10,913 inpatients and 28,954 out-patients, of whom 27,300 were said to have been cured: J. D. Chambers, Population, economy, and society in pre-industrial England, London, Oxford University Press, 1972, p. 99. In Manchester the governing committee of the Royal Infirmary laid great emphasis on cleanliness and provided baths in the year the institution was opened (1755). By 1781 patients were treated at home for infectious diseases such as smallpox, and after 1790 poor women were delivered in their homes. The Manchester doctors also pioneered 


\section{E. G. Thomas}

The access to the Radcliffe hospital provided for the poor of Oxfordshire and Berkshire did not, in the eighteenth century, definitely contribute to the death rate. Many patients returned home "cured" or, at least, "relieved". It might well be that local hospitals did, after all, make some contribution to the fall in mortality in the latter part of the eighteenth century. This would probably apply to the sick poor, for many entered hospital as casualties or with non-infectious diseases and were given treatment in conditions which at least were an improvement on their home environment. Many of them who were living at subsistence level in unfavourable domestic conditions might have benefited to the extent that the duration of the illness was shortened. In this way the hospitals probably contributed in a small way to the reduction of the mortality rate in the parishes themselves in the eighteenth century. 68

The dispensaries might also have made their contribution in the second half of the eighteenth century, providing services for the poor when they had little other assistance. That at Colchester, for example, was established by the benevolence of the local inhabitants and provided medical relief to the poor every day, as well as home visits where necessary. 69

Until recently the effect of inoculation appears to have been underestimated. It has been suggested that there are far too many imponderables involved to reach any positive conclusion - factors such as the percentage of the population affected, the age incidence of the disease, and the possibility of a developing immunity. Further, it is argued that the substantial decline of smallpox cannot be confirmed by national statistics, and that the effect of inoculation is not accepted by virologists. ${ }^{70}$ Thus a significant and continuous decline in mortality by this agency cannot be proved.

However, more recently, it has been argued that smallpox was a widespread cause of death and that inoculation, if practised on an extensive scale, could have "significantly contributed to the reduction of smallpox mortality during the period 1770-1840".71 Certainly epidemics could be serious in villages and small towns, and the evidence in Berkshire, Essex, and Oxfordshire points to fairly extensive use of inoculation,

the use of cod liver oil treatment for rickets: W. H. Chaloner, 'Manchester in the latter half of the eighteenth century', Bull. John Rylands Library, 1959, 42: 52-55. See also, G. B. Hindle, Provision for the relief of the poor in Manchester, 1754-1826, Manchester University Press for the Chetham Society, 1975.

68 A study of the Norfolk and Norwich Hospital has shown that the in-patients' death rate was never more than 4.5 per cent in the period 1772-1810, whilst the "cured" figure was 66 per cent, with nearly 80 per cent "cured" or "relieved". Of the out-patients, roughly half were "cured" in the 1770 s, and 70 per cent "cured" or "relieved". Though the pauper intake was limited (infectious cases were excluded and so were children under six or seven), the hospital did take numbers of the sick poor from an unfavourable environment and provided effective treatment - particularly in the period 1780-1810: S. Cherry, 'The role of a provincial hospital: the Norfolk and Norwich Hospital, 1771-1800', Population Studies, 1972, 26: 291, 306. E. M. Sigsworth, refers to W. Woolcombe, Remarks on the frequency of different diseases, 1808 , who claims that in no English hospital did the death rate exceed 1 in 11: 'Gateways to death? Medicine, hospital and mortality, 1700-1850', in P. Mathias (editor), Science and society 1600-1900, Cambridge University Press, 1972, p. 102. See also, Chambers, op. cit., note 67 above, p. 99; and Neil L. Tranter, Population since the industrial revolution: the case of England and Wales, London, Croom Helm, 1973, pp. 84-86.

69 The Newcastle Infirmary provided free medicine and a free casualty service for the poor from 1778 . By the 1820 s it could expect about 5,000 cases annually and provided a house visiting system also: McCord, op. cit., note 58 above, p. 98.

70 Glass and Eversley (editors), op. cit., note 14 above, p. 17; McKeown, Brown and Record, op cit., note 66 above, p. 346.

71 Razzell, op. cit., note 35 above, p. 149. 
particularly in the rural areas from the 1760s. 72 Whilst attributing the whole of the reduced death rate to inoculation is probably an exaggerated viewpoint, the treatment was so widespread, certainly in these three counties, that it might well have made a contribution to the falling death rate - particularly in the villages. ${ }^{73}$

Certain problems remain, however. One is the lack of definition of the cause of death in so many parish registers. Another is the fact that inoculation was resisted by some local authorities and thus the problem of uniform treatment - or rather lack of it - must be taken into consideration. Inoculation was also unpopular with many individuals. Lastly, more statistics are needed for the rural areas and thus more local research needs to be done in this field. Nevertheless, the case for inoculation remains a plausible one. It probably contributed to, but was not responsible entirely for, the "take off" in population growth after the middle of the eighteenth century. ${ }^{74}$

Parishes were equally keen to introduce vaccination and, from the first decade of the nineteenth century, the poor were often provided with free treatment. The evidence for the effective results of vaccination is more widespread than that for inoculation. ${ }^{75} \mathrm{It}$ is reasonably certain that vaccination in the early nineteenth century was increasingly accepted as an effective treatment for preventing smallpox and also for countering death from the disease. The London evidence is indicative of some effective factor tending to diminish mortality. It is possible that smallpox declined in virulence about this time, but this would be more difficult to substantiate than the obvious effect of vaccination. 76

In the urban areas, towns like Chelmsford and Hungerford were making efforts at improving environmental conditions - both in workhouses and, in the case of Chelmsford, in general conditions in streets, courts and the houses of the poor. Such attempts must have at least mitigated some of the unhealthy conditions and contributed in a small degree to the decrease of mortality.

72 Cf. D. V. Glass, "Contemporary evidence suggests . . . that it was the upper group who adopted inoculation more widely": in Glass and Eversley (editors), op. cit., note 14 above, p. 18. Also cf., K. F. Helleiner, "Its practice remained limited and its value was, moreover, doubtful": "The vital revolution reconsidered', in ibid., p. 84. Yet an Essex resident could write in 1765: "Many of my neighbours are daily going to be inoculated and the practice is becoming general throughout the country": Brown, op. cit., note 10 above, p. 146, quoting the Ipswich Journal, 27 April 1765.

$73 \mathrm{Cf}$. H. J. Habakkuk, Population growth and economic development since 1750, Leicester University Press, 1972, p. 35; Chambers, op. cit., note 67 above, p. 100. Cf., however, the comments of Van Zwanenberg, op. cit., note 38 above, pp. 82-83.

${ }^{74}$ For detailed arguments on these points, see Tranter, op. cit., note 68 above, pp. 81-84.

75 E.g., in Nottingham the death rate in 1795 was 35.7, but by 1801 had fallen to 30.8, "almost all of which can be accounted for by the fall of the child death-rate from 21.8 to 17.3 per thousand". Free vaccination was introduced into the town in $1800:$ J. D. Chambers, 'Population change in a provincial town: Nottingham 1700-1800', in L. S. Pressnell (editor), Studies in the industrial revolution, presented to Thomas S. Ashton, London, Athlone Press, 1960, p. 122. McKeown and Brown, op. cit., note 66 above, p. 305, concede that vaccination might have contributed to the decline of the death rate. Vaccination was quickly adopted after 1800 in Sweden and, after a serious epidemic in 1800-01, the number of deaths decreased considerably. In the period 1791-1815 the average life expectancy increased for children up to ten years of age, though it decreased for adults of twenty years and over: G. Utterström, 'An outline of some population changes in Sweden c. 1660-1750 and a discussion of some current issues', in Glass and Eversley (editors), op. cit., note 14 above, pp. 545-546.

76 Gale, op. cit., note 58 above, pp. 55, 62 . 